\title{
Formation of HEls students' soft skills using distance learning platforms in foreign language teaching
}

\author{
Shchehlova A.* \\ National University of Food Technologies, Kyiv, Ukraine
}

Received: 19.02.2021 Accepted: 22.03.2021

\begin{abstract}
The article is devoted to the implementation of modern distance learning technologies while teaching and studying Business English by the students for non-philological specialties. This research aims to identify the impact of distance learning platforms on the formation of soft skills. In the course of the research, the conceptual apparatus of distance learning is concretized; the positive and negative aspects of the new education system using etechnologies for the educational process in higher education institutions is highlighted; the effectiveness of distance technologies is analyzed in the context of soft skills development. The pedagogical ways of introducing multimedia teaching aids in learning a foreign language as a key condition for the fundamental training of a qualified specialist focused on meeting the needs of the modern market are described in detail. Based on the behavioral approach and analysis and synthesis of data from domestic and foreign literature, a comparative study of the theory and practice of introducing distance learning, it has been proved that with the change in educational trends and versatility of training courses, competition in the labor market is growing and in order to gain an advantage over competitors, students have no other choice than adding value to their professional skills with soft skills to showcase their true potential. It is noted that one of the most pressing problems in the field of digitalization of the educational process is the reform of curricula in order to adapt universities to the demands of the labor market. It has been proven that the effectiveness of achieving the triune goal (especially the developmental one) directly depends on the chosen forms and methods of teaching, and the inclusion of information and communication technologies is a consequence of the growing share of national GDP, which covers new technological industries and the high-level service sector. The challenges facing the modern higher education system during the pandemic is a step towards a new stage in its development and contextualisation, where the teacher acts as a mediator. In this regard, and with the aim of developing flexible skills of future specialists, distance learning platforms in learning a foreign language are considered as a way to solve complex problems, innovations and creativity, visualize new markets, understand social and global consequences, work in a new multi-faceted environment and with people of different cultures and countries, developing new products and services.
\end{abstract}

Key words: soft skills; contextualisation; higher education institutions (HEls); versatility; employment-oriented skills; facilitator.

\section{Формування гнучких навичок у здобувачів вищої освіти при використанні платформ дистанційного навчання у викладанні іноземної мови}

\author{
Щеглова А. 0. \\ Національний університет харчових технологій, Київ, Україна
}

\begin{abstract}
Анотація. Стаття присвячена питанням впровадження сучасних дистанційних освітніх технологій під час вивчення англійської мови бізнес спрямування здобувачами не філологічних спеціальностей. Дане дослідження спрямоване на виявлення впливу платформ дистанційної освіти на формування гнучких навичок (soft skills). У ході дослідження конкретизується понятійний апарат дистанційного навчання; виокремлюються позитивні і негативні сторони нової системи навчання із застосуванням електронних технологій для навчального процесу в закладах вищої освіти; аналізується ефективність дистанційних технологій в контексті розвитку гнучких (м'яких) навичок. Детально схарактеризовані педагогічні шляхи впровадження мультимедійних засобів навчання під час вивчення іноземної мови як ключової умови фундаментальної
\end{abstract}

Corresponding Author: Shchehlova Alla Oleksandrivna. Tel. +38097 29735 79. E-mail: allegro89@bigmir.net National university of food technologies, Volodymyrska str, 68, Kyiv, Ukraine, 01033.

Biдnовідальний автор: Щеглова Алла Олександрівна. Тел. +380972973579. E-mail: allegro89@bigmir.net Національний університет харчових технологій, вул. Володимирська, 68, м. Київ, Україна, 01033. 
підготовки кваліфікованого фахівця, орієнтованого на задоволення потреб сучасного ринку. На основі біхевіорального підходу та аналізу і синтезу даних вітчизняної та зарубіжної літератури, компаративного вивчення теорії і практики впровадження дистанційного навчання доведено, що зі зміною освітніх тенденцій та універсальністю навчальних курсів конкуренція на ринку праці зростає і щоб отримати перевагу над конкурентами, студентам не залишається іншого вибору, крім як додавати цінності своїм професійним навичкам за допомогою м'яких навичок, щоб продемонструвати свій справжній потенціал. Зазначено, що однією із найактуальніших проблем у сфері діджиталізації навчального процесу $є$ реформа навчальних програм з метою адаптації вищих навчальних закладів до запитів, що надходять із ринку праці. Доведено, що ефективність досягнення триєдиної мети (в особливості розвивальної цілі) напряму залежить від обраних форм та методів навчання, а включеність інформаційно-комунікаційних технологій $€$ наслідком постійно зростаючої частки національного ВВП, що охоплює нові технологічні галузі та сектор послуг високого рівня. Виклики, перед якими постала сучасна система вищої освіти в період пандемії, стали кроком до нового етапу іï розвитку та контекстуалізації, де викладач виступає в ролі посередника. У зв'язку з цим та з метою розвитку гнучких навичок майбутніх фахівців платформи дистанційного навчання під час вивчення іноземної мови розглядаються як шлях до розв'язання складних проблем, інновацій та творчості, візуалізації нових ринків, розуміння соціальних та глобальних наслідків, роботи в новому середовищі багатогранності та з людьми різних культур і країн, розробляючи нові продукти та послуги.

Ключові слова: гнучкі навички; контекстуалізація; заклади вищої освіти (3ВО); багатогранність; навички, орієнтовані на працевлаштування; посередник.

\title{
Формирование гибких навыков у соискателей высшего образования при использовании платформ дистанционного обучения в преподавании иностранного языка
}

\author{
Щеглова А. А. \\ Национальный университет пищевых технологий, Киев, Украина
}

\begin{abstract}
Аннотация. Статья посвящена вопросам внедрения современных дистанционных образовательных технологий при изучении английского языка бизнес направления соискателями не фрилологических специальностей. Данное исследование направлено на выявление влияния платформ дистанционного образования на формирование гибких навыков (soft skills). В ходе исследования конкретизируется понятийный аппарат дистанционного обучения; выделяются положительные и отрицательные стороны новой системы обучения с применением электронных технологий для учебного процесса в учреждениях высшего образования; анализируется эффективность дистанционных технологий в контексте развития гибких (мягких) навыков. Подробно охарактеризованы педагогические пути внедрения мультимедийных средств обучения при изучении иностранного языка как ключевого условия фундаментальной подготовки квалифицированного специалиста, ориентированного на удовлетворение потребностей современного рынка. На основе бихевиорального подхода и анализа и синтеза данных отечественной и зарубежной литературы, сравнительного изучения теории и практики внедрения дистанционного обучения доказано, что с изменением образовательных тенденций и универсальностью учебных курсов конкуренция на рынке труда растет и чтобы получить преимущество над конкурентами, студентам не остается другого выбора, кроме как добавлять ценности своим профессиональным навыкам с помощью мягких навыков, чтобы продемонстрировать свой истинный потенциал. Отмечено, что одной из самых актуальных проблем в сфере диджитализации учебного процесса является реформа учебных программ с целью адаптации вузов к запросам, поступающих с рынка труда. Доказано, что эффективность достижения триединой цели (в особенности развивающей) напрямую зависит от выбранных форм и методов обучения, а включенность информационно-коммуникационных технологий является следствием растущей доли национального ВВП, что охватывает новые технологические отрасли и сектор услуг высокого уровня. Вызовы, перед которыми стоит современная система высшего образования в период пандемии, стали шагом к новому этапу ее развития и контекстуализации, где преподаватель выступает в роли посредника. В связи с этим и с целью развития гибких навыков будущих специалистов платфрормы дистанционного обучения при изучении иностранного языка рассматриваются как путь к решению сложных проблем, инноваций и творчества, визуализации новых рынков, пониманию социальных и глобальных последствий, работы в новой среде многогранности и с людьми разных культур и стран, разрабатывая новые продукты и услуги.
\end{abstract}

Ключевые слова: гибкие навыки; контекстуализация; высшие учебные заведения (ВУЗы); многогранность; навыки, ориентированные на трудоустройство; фасилитатор. 


\section{Bcmyn}

Сучасна система вищої освіти зазнає змін, що в свою чергу приводить до появи нових технологій та форм організації навчального процесу. Спостерігається тенденція розвитку дистанційної освіти в Україні, де звичне академічне оточення зазнає трансформацій і змінює контекстуальну парадигму. Реалізація технології дистанційного навчання забезпечується шляхом розробки моделі використання віртуально-навчальних середовищ та готових платформ для навчання.

Провідна роль інформаційно-комунікаційних технологій (IКT) у суспільстві знань вимагає нового підходу до освіти, орієнтованого на використання відкритого контенту та ресурсів, що сприяють постійному підключенню, дозволяючи здобувачам вищої освіти та викладачам отримувати доступ до спільних робочих областей та сприяти їм у будь-який час [10; 12; 15].

Методи дистанційного та змішаного навчання все більше використовуються в освітньому процесі вищих навчальних закладів, адже вони посилюють роль методів активного пізнання. Сучасні технології дозволяють сформувати навчальні групи в онлайн-спільноті, використовувати електронні класи, технологію вебінарів та різноманітні електронні ресурси [18]. Популярність інтегрування ІКТ в навчальний процес обумовлена такими факторами:

1. Соціальні - потреба в ознайомленні та опануванні нових технологій;

2. Економічні - стратегічна інформатизація всіх секторів економіки;

2. Зовнішні - необхідність, викликана, наприклад, пандемією чи будь-яким іншим впливом зовнішнього середовища;

3. Професійні - підготовка студентів до майбутньої професійної діяльності;

4. Педагогічні - підвищення рівня знань, мотивації, гнучкості та ефективності виконання навчальних програм $[4 ; 6]$.

Вивчення іноземної мови бізнес спрямування $є$ обов'язковою компонентою програм закладів вищої освіти. Світовий ринок праці вимагає від молодих спеціалістів не лише приділяти значення професійним знанням, а й вміти швидко адаптуватися в нових умовах та займатися самоосвітою. Сучасні роботодавці шукають кандидатів, які не лише можуть добре виконувати свою роботу, але і які також можуть відповідати принципам культури компанії та ефективно взаємодіяти 3 іншими працівниками. Для того, щоб успішно робити ці речі, студентам потрібно розвивати м'які навички. М'які / гнучкі навички - це атрибути, які дозволяють вступати у значущі взаємодії з іншими. Оскільки більшість робочих місць вимагають командної роботи, важливо володіти м'якими навичками, щоб підвищити рівень власної конкурентоспроможності серед інших кандидатів [8; 17; 27]. Такі навички допоможуть підвищити продуктивність у кар'єрі, налагодити професійні стосунки та розвиватися за обраним напрямком. Професійно-ділова комунікація іноземною мовою та інтеграція м'яких навичок у процес дистанційного навчання нерозривно пов'язані між собою [9]. На сьогодні англійська мова стала глобальною мовою, і вона використовується для всіх аспектів життя, включаючи науку та технології. Тому відсутність володіння англійською мовою може зробити людей нездатними конкурувати з іншими в цю епоху. Проте викладання та вивчення англійської мови не може зосереджуватись лише на опановуванні мовою, воно також має зосередитись на тому, як розвивати у студентів гнучкі навички. Отже, викладачі англійської мови мають інтегрувати процес викладання англійської мови в умовах дистанційного навчання зі спробою формування м'яких навичок студентів [14;21;23]. Процес навчання повинен бути спрямований на те, щоб дати студентам більше можливостей для розвитку їхнього потенціалу та творчості.

У зв'язку із широким впровадженням платформ дистанційного навчання при вивченні іноземних мов та попитом на розвиток м'яких навичок іноземна мова постає холдером значного потенціалу у підготовці всесторонньо розвинених фрахівців [4; 22]. Отже, актуальність даної теми пояснюється необхідністю дослідження факторів успішного засвоєння мовного матеріалу та особливостей і тактик використання сучасних інформаційних технологій на онлайн заняттях з англійської мови $з$ метою розвитку гнучких навичок.

Поняття гнучких / м'яких навичок (soft skills) досліджувалося різними вітчизняними і закордонними вченими та науковцями [3; 5; 7]. Багато досліджень 3 даної проблематики встановили, що гнучкі навички необхідні для успішної кар'єри так само як і фахові знання та вміння, хоча заклади вищої освіти не 
приділяють належної уваги розвитку гнучких навичок у студентів [19]. Введення таких елементів у процес викладання іноземної мови, а особливо використовуючи платформи дистанційного навчання, $\epsilon$ необхідною потребою сьогодення, оскільки це стимулює лінгвістичний, когнітивний та соціальний розвиток здобувачів вищої освіти [11; 16; 26].

Meта роботи: охарактеризувати роль платформ та сервісів дистанційного навчання під час занять з іноземної мови бізнес спрямування у формуванні гнучких навичок у здобувачів вищої освіти, а саме вплив внутрішніх та зовнішніх факторів на даний процес та основні педагогічні інструменти розвитку гнучких навичок у навчальному середовищі е-фрормату.

\section{II Матеріал і методи дослідження}

Під впливом прискореного розвитку технологій та відповідних соціально-економічних змін перед закладами вищої освіти постала необхідність у швидкому розгортанню технологій дистанційного навчання, адаптування чинних програм до того інструментарію, яким володіє кожна з можливих платформ та сервісів. Дистанційна освіта надає можливість навчатися та отримувати необхідні знання віддалено від навчального закладу в будь-який зручний час шляхом інформаційно-комунікаційних технологій. Сьогодні поняття дистанційності передбачає саме онлайн-освіту. Програма дистанційного навчання може бути повністю дистанційною, або поєднанням дистанційного навчання та традиційного навчання в аудиторії (так зване гібридне або змішане) [1]. Широкомасштабна інтерактивна участь та відкритий доступ до всесвітньої павутини є ключовими характеристиками дистанційної освіти. Такі терміни, як розподілене навчання, електронне навчання, онлайн-навчання, віртуальний клас, використовуються приблизно синонімічно дистанційній освіті. Дистанційне навчання може бути синхронним та асинхронним спілкуванням в Інтернеті в інтерактивному навчальному середовищі або віртуальних спільнотах, замість фізичного класу [12].

Існує багато онлайн-платформ та сервісів для навчання, які пропонують можливість вчитися чи створювати онлайн-курси. Кожен викладач для свого заняття має можливість обрати саме той інструмент, який якнайкраще задовольняє потреби як слухачів, так і відповідає дидактичним принципам. Ключовим моментом $є$ наявність одного єдиного навчального простору для університету, який би дозволяв об'єднати педагогів, адміністраторів та студентів в одну надійну та інтегровану систему для створення персоналізованого навчального середовища, наприклад, в системі Moodle. Moodle безкоштовна і відкрита система управління навчанням, яка може поєднувати у собі комунікацію між викладачами та студентами. Надає безліч можливостей, серед яких: виконання завдань, завантаження файлів, обмін повідомленнями, оцінювання та календар подій. Також, у Moodle інтегровані сучасні технології для перевірки робіт на плагіат плагіатчекером Unicheck. А безкоштовні веб-сервіси, типу Google Classroom, чи комунікаційні платформи, типу Zoom та Skype, адаптувати та використовувати 3 метою спрощення створення, поширення і класифікації завдань безпаперовим шляхом безпосередньо на практичних заняттях з іноземної мови. У сервісі Google Classroom можна завантажувати роботи, редагувати їх, оцінювати тестові або контрольні роботи. Дана система проста і зрозуміла в роботі. Вона дозволяє планувати навчальний процес, створювати курси, спілкуватися одночасно з усіма студентами та багато іншого. Zoom - платформа для відеоконференцій та викладання, яка нещодавно зросла в популярності; має вбудовану інтерактивну дошку, простір для до 100 студентів, спільний доступ до файлів, окремі кімнати для групової роботи та функції чату. Zoom має безкоштовний план, хоча сеанси можуть тривати до 40 хвилин (тоді потрібно буде перезапустити сеанс, щоб продовжити, або оновити до облікового запису Pro). У багатьох ситуаціях технології насправді можуть полегшити взаємодію. Це однаково може стосуватися і взаємодії у віртуальному навчальному середовищі - якщо правильно керувати ними, можливості для стимулювання лінгвістичного розвитку можуть бути оптимізовані, і студенти матимуть змогу взаємодіяти між собою [13]. Адже вивчення іноземної мови - це не лише розвиток навичок читання і письма, це передбачає двосторонню комунікацію, а отже взаємодію, в якій викладач займає опосередковану позицію. Викладання іноземних мов давно перестало бути статичною дисципліною, в якій викладачі $\epsilon$ переважно передавачами декларативних знань, тобто фактів чи інформації. У наш час викладачів англійської мови краще розуміти як фрасилітаторів навчання, які надають можливості для навчання своїм учням та забезпечують зворотний зв'язок для підтримки вдосконалення. Отже, суть викладання полягає не в чомусь фіксованому, а швидше динамічному, 
пристосовуючись до контексту та ситуації, в якій опиняється кожен викладач. Сприяння навчанню за допомогою технологій $є$ висококваліфікованою справою, і в багатьох контекстах можна запропонувати дійсно корисну підтримку групі, надаючи студентам можливість навчатися новими та цікавими способами.

Як і у більшості методів навчання, онлайн-навчання також має свій власний набір переваг та недоліків, розуміння яких допоможе закладам вищої освіти у створенні стратегій для більш ефективного проведення занять, забезпечуючи безперебійний навчальний процес для студентів. До переваг дистанційного навчання іноземним мовам відноситься:

1. Ефективність - онлайн навчання пропонує викладачам ефективний спосіб проведення занять для студентів. Інтернет-навчання має ряд інструментів, таких як відео, PDF-фрайли, і викладачі можуть використовувати всі ці інструменти як частину своїх занять. Розширивши план занять за рамки традиційних підручників, включивши Інтернет-ресурси, можна досягти вищого рівня ефективності.

2. Доступність часу та місця - можливість відвідувати та проводити заняття з будь-якого місця на вибір. Крім того, онлайн-заняття можна записувати, архівувати та ділитися ними для подальшого використання. Це дозволяє студентам отримати доступ до навчального матеріалу, коли їм комфортно.

3. Фінансова доступність - Інтернет-освіта $€$ набагато доступнішою у порівнянні 3 офллайннавчанням. Це пов'язано з тим, що навчання в Інтернеті виключає витрати на проїзд та харчування студентів, а головне - нерухомість. Крім того, усі навчальні матеріали доступні в Інтернеті, таким чином створюючи безпаперове навчальне середовище, яке $€$ більш доступним, а також корисно для навколишнього середовища.

4. Універсальність - підходить для різноманітних стилів навчання. Інтернет-систему навчання з її різноманітними можливостями та ресурсами можна персоналізувати різними способами. Це найкращий спосіб створити ідеальне навчальне середовище, яке відповідає потребам кожного студента [15].

Серед недоліків дистанційного навчання іноземним мовам виділяється:

1. Складність тривалої концентрації уваги на екранах - в традиційній системі освіти викладач значною мірою може впливати на поведінку студентів; онлайн навчання може змістити акцент на контент - важливо, щоб онлайн-заняття були чіткими, цікавими та інтерактивними, щоб допомогти студентам зосередитися на матеріалі.

2. Почуття ізоляції - студенти можуть багато чому навчитися, перебуваючи серед своїх однолітків. Однак в Інтернет-класі існує мінімальна фрізична взаємодія між студентами та викладачами. Це часто призводить до відчуття ізоляції студентів. У цій ситуації вкрай важливо, щоб були наявні інші форми спілкування між учасниками освітнього процесу.

3. Підготовка викладачів - онлайн-навчання вимагає від викладачів базового розуміння використання цифрових форм навчання. Однак часто викладачі не розуміються у певних технологіях. Іноді вони навіть не мають необхідних ресурсів та інструментів для проведення онлайн-занять. Для боротьби з цим важливо, щоб навчальні заклади інвестували в підготовку викладачів з використанням останніх технологій, щоб вони могли безперешкодно проводити свої онлайн-заняття.

4. Керування часом на екрані - багато батьків стурбовані небезпекою для здоров'я, коли їхні діти проводять багато часу перед екраном. Іноді у студентів виникає погана постава та інші фрізичні проблеми через перебування перед екраном [18].

Створення ефективного навчального середовища в Інтернеті вимагає знань, часу, досвіду, таланту, відданості, великих навичок спілкування та справжньої пристрасті до навчання. 3 метою надання студентам ширших можливостей для спілкування, висловлювання власних думок домінантною формою навчання іноземної мови в онлайн-середовищі мають бути такі методи, які б сприяли відпрацьовуванню навичок правильного спілкування, відповідальності за результати спільної дії, толерантності та поваги до інших культур, розширення країнознавчих знань. Всі ці якості виробляються під час занять з іноземної мови через засвоєння норм та особливостей іншомовної комунікативної культури, побудови власного висловлювання та конструювання діалогу.

3 метою полегшення процесу адаптації до онлайн середовища необхідно особливий акцент зробити на етапі залучення студентів до занять, починаючи всі практичні заняття з оголошення цілей та скористатися при цьому чатом або інтерактивною дошкою, щоб поділитися тим, про що буде розповідатися під час занять, і пояснити, що очікується від студентів [16]. Це допоможе їм зосередитись 
і відчути, що вони перебувають у звичайному класі. В кінці заняття варто виділити час на аналіз цілей та досягнутих результатів. Звичний розпорядок та безпечне навчальне середовище дасть змогу швидше та ефективніше давати інструкції. Наприклад, традиційний початок заняття з іноземної мови має залучити всіх студентів і їх увагу (це може бути міні-гра, огляд або декілька запитань, орієнтованих на студентів), а потім відбувається перехід до роботи над планом заняття. Навчання має поєднуватися 3 енергійними іграми, ситуативними задачами тощо, щоб студенти могли ділитися своїми ідеями. Викладання іноземної мови з використанням онлайн сервісів дозволяє викладачеві давати інструкції всім студентам усно та в письмовій формі, при цьому студенти можуть підтвердити своє розуміння в чатах. Залежно від того, яка платфрорма використовується, часто є можливість ділитися матеріалами, документами та слайдами презентацій, а також демонструвати та використовувати інші заняття, такі як онлайн-вікторини та групові ігри. Управління онлайн-заняттями через технічні можливості може бути простішим, ніж звичайним аудиторним. Задача викладача, як посередника процесу, створити такі умови спілкування, щоб студенти почувались комфортно та отримували підтримку протягом усього заняття. Завдання на основі співпраці мають складати приблизно половину заняття, адже будучи відокремленими один від одного, не варто недооцінювати можливості спільної роботи. Багато платформ дозволяють об'єднати студентів у пари або групи для спільної роботи у спеціально відведених чатах. Викладач може заходити і виходити з цих кімнат, щоб стежити за тим, як ідуть справи, і давати відгуки, так само як і на звичайному занятті. Google Docs, Etherpad та Dropbox Paper дозволяють студентам працювати над написанням спільних робіт та творчих проектів, a Flipgrid записувати та ділитися власними відео, що гарно підходить для проведення Інтернет-презентацій. Отже, у процесі вивчення іноземної мови бізнес спрямування відбувається активне формування професійних навичок студентів (hard skills). Хоча побудова правильних освітніх основ та здобуття відповідної кваліфікації $€$ важливими, цього недостатньо для визначення успіху в сучасну епоху. У XXI столітті м'які навички (soft skills) та готовність вчитися є ключем до успіху.

Hard skills або професійні навички - це засвоєні здібності, набуті та вдосконалені за допомогою практики, повторення та навчання. Професійні навички - важливі, оскільки вони підвищують продуктивність та ефективність праці, а згодом покращують задоволеність працівників. Володіння професійними навичками означає майстерність і вміння людини виконувати конкретну задачу або серію завдань для виконання роботи. Однак такі навички самі по собі не перетворюються на успіх у бізнесі, оскільки працівникам також потрібно використовувати інші, м'які навички. Під терміном «soft skills» / м'які / гнучкі навички мається на увазі динамічне поєднання когнітивних та метакогнітивних навичок, міжособистісних, інтелектуальних та практичних навичок та етичних цінностей. М'які навички допомагають людям адаптуватися та поводитися позитивно, щоб вони могли ефрективно розв'язувати проблеми свого професійного та повсякденного життя [5].

Щоб зрозуміти важливість м'яких навичок у сучасну епоху, треба звернутися до статистики. Дослідження, проведене Гарвардським університетом, показало, що до 80\% досягнень у кар'єрі людини визначаються м'якими навичками і лише 20\% твердими навичками. Інші проведені дослідження йдуть ще далі - змінюючи ці показники на 85\% та 15\% відповідно [8]. Це пов'язано з тим, що м'які навички можуть бути надзвичайно важливими для того, щоб дати перевагу на дедалі більш конкурентоспроможному ринку праці. Більшість роботодавців сьогодні прагнуть наймати, утримувати та просувати людей, винахідливих, етичних, надійних та мотивованих. Наявність ефективного спілкування, готовність працювати і вчитися та позитивне ставлення дуже високо ціняться на сучасному робочому місці.

На фрормування гнучких навичок впливає багато факторів. Гнучкі навички пов'язані з емоційним інтелектом людини та знаходяться у комплементарних відносинах 3 професійними навичками. Неможливо відокремити одну групу навичок від інших, вони завжди знаходяться у тісному взаємозв'язку. Базисом для формування м'яких навичок $€$ середовище організаційної культури, тобто академічне оточення. Найпростіший спосіб прищеплення цих навичок - це їх моделювання. Коли викладачі демонструють це власним прикладом, студенти не тільки розуміють цінність і відчувають натхнення прийняти їх, вони бачать, як і коли застосовувати їх. Це підкреслює, що навички набуваються і розвиваються спостереженнями. Оскільки вивчення іноземної мови бізнес спрямування - це набуття практичних навичок, то більшість завдань засновуються на принципу невідривності від практичної 
діяльності. Отже, таким чином відбувається процес формування професійних навичок, а моделюючи ситуації, наближені до реального життя, студенти розвивають і власні гнучкі навички. (рис. 1).

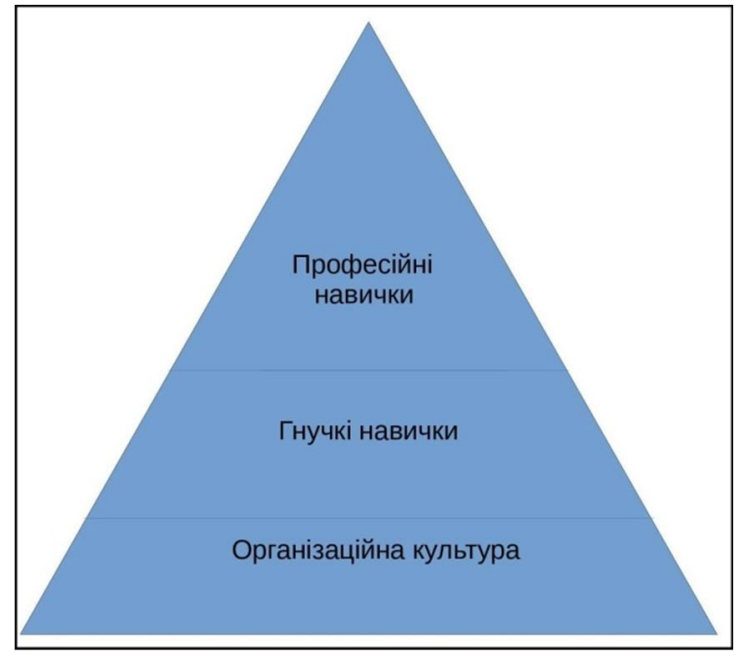

Рис. 1. Середовище формування гнучких навичок

Оскільки бізнес-курс англійської мови має широкі можливості для розвитку гнучких навичок та навичок, орієнтованих на працевлаштування, то на онлайн заняттях відбувається поєднання традиційних аспектів читання, письма та говоріння з новими інтерактивними засобами масової інфрормації для сприяння навчанню студентів [7]. Студенти мають можливість відвідувати як заняття в режимі реального часу, так і самостійно навчатися в динамічному навчальному середовищі в Інтернеті. На таких заняттях вони разом з викладачами працюють над мультимедійними завданнями, беруть участь у дискусіях та груповій роботі з іншими студентами в Інтернет-середовищі, знайомляться 3 яскравим, віртуальним досвідом, який дозволяє застосувати навички спілкування, отримують відгуки викладачів про всі завдання, виконують семестрові завдання та тести в кінці кожного курсу. Матеріали курсу створюються з урахуванням студентів, першою мовою яких не є англійська. Студенти мають можливість взаємодіяти з матеріалами у письмовому чи відео форматі (із субтитрами) та, у своєму власному темпі, перевіряти будь-який незнайомий словниковий запас під час занять у прямому ефірі.

М'які навички включають елемент міжособистісної взаємодії, тобто активне слухання, роботу в команді, прийняття рішень та навички впливу. Опанування цих навичок допоможе студентам швидше прогресувати та стати більш самостійними [3]. Один із найкращих способів бути хорошим комунікатором - це слухати співрозмовника. Студенти мають проявляти інтерес до того, що хтось говорить, задаючи уточнювальні запитання та переформулюючи сказане, щоб переконатися, що вони їх повністю зрозуміли. Чим більше вони слухатимуть, тим легше буде відповісти. Для ефективного управління працівниками та клієнтами студенти повинні мати можливість впливати на інших. Це можна зробити, вибудувавши взаємозв'язок, пояснивши, чому вони щось роблять, ставлячи правильні запитання. Ключ до закриття продажів, отримання вигідної ціни за щось чи керування щасливою командою - це мистецтво переговорів. Успішні учасники переговорів визначають свої цілі перед початком роботи, повністю готуються підтримати свої позиції. Студенти повинні навчитися чітко висловлюватися та передавати своє повідомлення з якомога меншою кількістю слів. Те, як вони застосовуватимуть ці навички, буде залежати від проблеми, про яку йдеться, ситуації та з ким вони спілкуються, тому викладачеві як фасилітаторові потрібно буде відповідно скорегувати їх поведінку під час виконання завдань. Приклади гнучких навичок, що розвиваються на онлайн заняттях з іноземної мови бізнес спрямування, наведені на рис. 2.

Високотехнологічність та діджиталізація - феномени, які стали перманентним епіцентром людського розвитку, тому фактично неможливо уявити освітню сферу без впровадження інформаційнокомунікаційних технологій не лише з дидактичною метою, а й 3 розвивальною, особливо для напрацювання гнучких навичок як об'єктивної вимоги сучасного ринку праці. 




Рис. 2. Гнучкі навички, які формуються при вивченні іноземної мови онлайн

\section{III Результати}

Досліджуючи результативність дистанційних технологій на заняттях з іноземної мови бізнес спрямування в контексті формування та розвитку гнучких навичок можна виділити особливо ефективне формування наступних:

1. Прагнення до саморозвитку та самонавчання - при дистанційному навчанні студент поступово стає більш дисциплінованим та вчиться самостійно організовувати власне навчання;

2. Навички управління часом - для того, щоб вчасно виконати певний об'єм завдань, студенти самостійно визначають, коли працювати і планують свій час, таким чином розвиваючи тайм менеджмент;

3. Навички командної роботи, наставництва і делегування - під час парної чи групової роботи в чат-кімнатах студенти вчаться допомагати один одному без термінової участі викладача.

В ході дослідження виявлено, що можна сприяти розвитку гнучких навичок на занятті з іноземної мови бізнес спрямування. Інтегрування soft та hard skills $€$ гарною ідеєю, тому що просто викладати поняття м'яких навичок недостатньо, потрібне практичне підкріплення та розуміння того, що стоїть за формуванням гнучких навичок і в чому полягає складність. Отже, є приховані навички або компетенції, які потрібні як фундамент, на якому можна розвивати м'які навички. Цей необхідний фрундамент відомий як емоційний інтелект. Емоційний інтелект - це навчена здатність ідентифікувати, пояснювати, розуміти та виражати людські емоції здоровими та продуктивними способами. Без цих базових блоків здатність студента розуміти та використовувати м'які навички дуже обмежена. Наступним кроком $є$ визначення компетенцій м'яких навичок, яким потрібно навчати, фундаментальних блоків, на яких будується компетенція м'яких навичок. Ці фундаментальні блоки є компетенцією емоційного інтелекту. Навички міжособистісного спілкування - соціальні навички, і охоплюють те, як взаємодіяти з іншими людьми та представляти себе в соціумі. Вони включають такі групи навичок, як навички міжособистісного спілкування, контроль над своїми емоціями, спілкування на роботі, спілкування в мережі, реагування на конфрлікти та допомога. Основними навичками базового емоційного інтелекту, необхідними для розвитку цих міжособистісних навичок, є:

1. Самооцінка - рівень сприйняття особистої цінності; виступає найважливішою компетенцією емоційного інтелекту для розвитку позитивних стосунків, оскільки вона диктує, як люди можуть ставитись до себе в соціальних ситуаціях. Якщо люди почуваються добре до себе, вони також демонструють позитивні почуття щодо людей, які їх оточують.

2. Міжособистісне усвідомлення - спочатку починається з внутрішньо-особистісного усвідомлення або усвідомлення себе. Як тільки люди усвідомлюють себе, вони можуть усвідомлювати інших. Поінформованість інших також вимагає чіткого розуміння того, як інші можуть реагувати на них.

3. Емпатія - охоплює, як відчути, зрозуміти та прийняти думки, почуття та поведінку іншої людини.

4. Опорне середовище - ступінь впливу друзів, родини, однолітків на досягнення студента та те, як вони можуть позитивно заохочувати студента у досягненні особистих цілей та покращенні стосунків. 
Отже, ігноруючи основні необхідні компетенції емоційного інтелекту, не можливо навчити компетентностям м'яких навичок.

\section{IV Обговорення}

Аналіз досліджень дозволив виявити, що концепт гнучких навичок та особливості їх формування на онлайн заняттях з іноземної мови бізнес спрямування, набуває широкої актуальності, адже існує зацікавленість у розвитку інноваційних підходів до навчання та необхідність інтегрування елементів, що дозволяють набувати гнучкі навички $[18,171]$.

Ми згодні з авторами, які вважають, що використання можливостей систем інформаційного управління навчанням з боку студентів та викладачів буде сприяти підвищенню якості навчання та розвитку м'яких навичок $[8,240]$. Платформи та сервіси дистанційного навчання стають обов'язковим елементом у процесі вивчення іноземної мови та розглядаються як засіб автентичного спілкування, обміну інформацією та власне її джерело. Ефективність формування гнучких навичок з використанням IКT залежить від чіткості формулювання інструкцій та завдань, правильно підібраного матеріалу відповідно до мовленнєвої компетенції студентів та потреб спілкування [27, 377]. Привабливість ІКТ визначається співпрацею викладача з учасниками заняття за допомогою технічного засобу у вигляді телефону, ноутбуку, проєкторної техніки, де викладачеві відводиться роль фрасилітатора, який координує процес творчо-пізнавальної активності, спрямовуючи роботу таким чином, щоб усі студенти долучалися до роботи у ході заняття та відсоток досягнення розвивального складника мети заняття підвищувався $[1 ; 5 ; 25]$.

Доведено, що особливу актуальність і значущість для формування гнучких навичок набуває командна робота у різних формах (мікрогрупи, робота в парах), тому що вона спрямовує команди до діалогічних та полілогічних видів взаємодії здобувачів (прослуховування повідомлень або представлення проєктів, що актуалізують певну проблему, підготовлених студентами відповідної групи, запитання, які поглиблюють розуміння суті теми, обговорення, дискусія, обмін думками) [10; 27].

Шляхом використання сучасних дистанційних платформ та сервісів відбувається конструювання вдосконаленого освітнього середовища. В контексті впровадження нових підходів та методів навчання іноземних мов фрормується нова культура педагогічної праці та вектора взаємодії «викладач-студент» $[23,34]$.

Як показують дослідження, поняття «soft skills» починає вживатися у наукових роботах американських та німецьких фахівців у галузі управління з 90-х pp. XX століття, пізніше даний концепт починає досліджуватися в системі освіти. Гнучкі навички прийнято розглядати в доповненні до технічних, професійних навичок (hard skills) [6; 10].

Проведене нами анкетування студентів щодо навичок, які, на їх думку, допомогли їм працевлаштуватися, виділило групи таких гнучких навичок, як самомотивація, знання основ робочої етики, спілкування та вміння працювати в команді - саме ті навички, на формування яких активно впливають заняття з іноземної мови бізнес спрямування, що підкреслює причинно-наслідковий зв'язок між вивченням іноземних мов та розвитком м'яких навичок [3]. Майже аналогічні результати опитування були отримані іншими дослідниками, зокрема С. А Шилова. та Г. В Корнюш також зазначають, що відбувається перехід від механічного засвоєння знань до опанування навичок самостійного пошуку та здобуття знань з активним формуванням практичних вмінь [27; 10].

Вища освіта зараз переорієнтовується та обирає вектор, спрямований на розвиток навичок, що мають попит на ринку праці. Основу модернізації складають перетворення на всіх рівнях, включаючи дистанційне і змішане навчання.

Ми згодні з твердженням вітчизняних вчених, що основними методами розвитку гнучких навичок слід вважати:

1. Самонавчання.

2. Навчання на досвіді інших, робота з ментором.

3. Вправи, що розвивають певні компетенції.

4. Кейс-методи [7; 15]. 
3 іншого боку, як показують дослідження [1; 3], рівень сформованості гнучких навичок, отриманих у процесі е-навчання, вказують на необхідність вдосконалення електронних курсів та підходів до навчання іноземної мови в онлайн середовищі.

\section{V Висновки}

3 виходом вищої освіти в Україні на новий рівень змінилися і підходи до навчального процесу та форм і методів його організації. Одним з видів інновацій в організації професійної освіти є введення дистанційного навчання. Дистанційне навчання - нова організація освітнього процесу, що використовує як традиційні методи навчання, так і нові ІКТ. Популяризація навчання іноземних мов з використанням дистанційних платформ та сервісів обумовлена сучасними світовими умовами. Оскільки навчання в Інтернеті стає інтегральною частиною досвіду вищої освіти, дане середовище впливає не лише на набуття практичних професійних навичок, а й на формування гнучких. Некогнітивні навички, такі як робота в команді, навички міжособистісного спілкування, міжкультурна компетентність та саморегуляція, $€$ цінними, хоча їх важко виміряти результатами вищої освіти, і вони звичайно перераховані серед навичок навчання двадцять першого століття, необхідних для успіху в економічній системі, заснованій на знаннях. Проаналізувавши вплив цих навичок на ринок праці, ми дійшли висновку, що некогнітивні навички з часом стають все більш важливими для робочої сили завдяки автоматизації багатьох рутинних завдань. Дистанційна освіта має багато переваг, але цей перспективний простір вимагає від педагога та студента переорієнтації, щоб гнучкі / некогнітивні навички можна було повною мірою практикувати та розвивати. В умовах електронного навчання важливо розглянути можливість використання аудіо- чи відео-програм, щоб стимулювати бесіду між студентами, а не використовувати лише текстові дошки для обговорення. Студенти також повинні брати участь у менших групах та дискусіях, де соціальні норми перевіряються та засвоюються, і може виникнути почуття приналежності. Навчання м'яким навичкам ускладнюється тим, що ці компетенції часто $є$ відкритими та комплексними, змінюючись в залежності від ситуації, вони опираються на досвід емоційного інтелекту особистості. Розвиток гнучких навичок вимагає більше часу, уваги та енергії, ніж може забезпечити одна навчальна подія. Отже, одного навчального втручання недостатньо для передачі м'яких навичок. Потрібна змішана стратегія з великою кількістю практики та зворотного зв'язку, що може природньо інтегруватися та забезпечитися курсом іноземної мови бізнес спрямування. Проведення детального аналізу особливостей застосування окремих платформ дистанційного навчання та шляхів усунення прогалин у процесі опанування як лінгвістичних аспектів, так і набуття та розвитку гнучких навичок, є перспективою подальших досліджень.

\section{Бібліографрічні посилання}

1 Биков В. Ю. Підвищення значущості інформаційно-комунікаційних технологій в освіті / Педагогіка і психологія. 2009. №1. C. 28-33.

2 Биков В. Ю., Кухаренко В. М., Сиротенко Н. Г., Рибалко О. В., Богачов Ю. М. Технологія створення дистанційного курсу : навчальний посібник ; за ред. В. Ю. Бикова та В. М. Кухаренка. Київ: Міленіум, 2008. 324 с.

3 Богдан Е. С. Развитие у студентов инженерных направлений soft skills как важный фактор их конкурентоспособности / Актуальные проблемы гуманитарных и естественных наук. 2017. № 2-4. С. 17-20.

4 Боднар С. В. Використання Інтернет-технологій у системі автономного вивчення професійно-орієнтованої іноземної мови студентами немовних спеціальностей / Інформаційні технології і засоби навчання. 2013. Том 34. № 2. С. $75-81$.

5 Briggs S. 30 Tips to Cultivate Soft Skills in Your Students / Open College.InformED. 2015. URL: https://www.opencolleges.edu.au/informed/features/30-ways-to-cultivate-soft-skills-in-your-students/ (дата звернення 02.01.2021).

6 Васильева И. А., Осипова Е. М., Петрова Н. Н. Психологические аспекты применения информационных технологий / Вопросы психологии. 2002. №3. С. 86.

7 Давыдова В. Слушать, говорить и договариваться: что такое soft skills и как их развивать. 2015. URL: http:/l theoryandpractice.ru/posts/11719-soft-skills (дата звернення 02.01.2021).

8 Длугунович H. A. Soft skills як необхідна складова підготовки IT-фрахівців / Вісник Хмельницького національного університету. 2014. № 6 (219). С. 239-242.

9 Коваль Т. І. Підготовка викладачів вищої школи: інформаційні технології у педагогічній діяльності : навч.-метод. посіб. Київ: Вид. центр НЛУ, 2009. 380 с.

10 Корнюш Г. В. Формування м'яких навичок у студентів закладів вищої освіти в контексті навчання іноземних мов / Викладання мов у вищих навчальних закладах освіти на сучасному етапі. Міжпредметні зв'язки. 2020. №36. С. 99-110. 
11 Костенко І. Г. Використання Інтернет-ресурсів на уроках англійської мови / Таврійський вісник освіти. 2013. № 1 (41). С. 170-176.

12 Костікова І. І. Роль комп'ютерних технологій в навчанні студентів / Новий колегіум. 2006. № 2 (33). С. 55-63.

13 Кухаренко В. М. Дистанційне навчання. Енциклопедичне видання : навчально-методичний посібник. Київ: ТОВ Редакція «Комп'ютер», 2007. $128 \mathrm{c.}$

14 Лапінський В. Електронні засоби навчального призначення - світовий досвід й українська освіта / Вища освіта України. 2011. №3. C. 487-495.

15 Malinina I. Blended Learning of English Language:Combining Online and Face-to-Face Teaching / Infonomic Society. London, 2012. P. 247-251.

16 Морська Л. І. Інформаційні технології у навчанні іноземних мов : навчальний посібник. Тернопіль: Астон, 2008. 256 с.

17 Mosquera I. Ideas to bring soft skills into the English classroom / British Council. Teaching English. 2018. URL: https://www.teachingenglish.org.uk/blogs/ingrid-mosquera-gende/ideas-bring-soft-skills-english-classroom (дата звернення 02.01.2021).

18 Нітченко Г. М., Ховрич М. О. Аналіз використання інформаційно-комунікаційних технологій у навчальному процесі / Вісник Чернігівського національного педагогічного університету. Серія : Педагогічні науки. 2015. Вип. 130. С. $169-172$.

19 Носкова Н. В. Інформатизація системи освіти та проблеми впровадження педагогічних програмних засобів у навчальний процес / Комп'ютер у школі та сім'ї. 2006. №5. С. 7-11.

20 Носкова Н. В. Проблема мотивації педагогів до використання інформаційно-комунікаційних технологій у навчальному процесі / Комп'ютер у школі та сім'ї. 2009. №1. С. 6-10.

21 Палагутина М. А., Серповская И. С. Инновационные технологии обучения иностранным языкам / Проблемы и перспективы развития образования: материалы междунар. заоч. науч.конф. Пермь : Меркурий, 2011. С. $156-159$.

22 Плугатарьова О. І. Використання інтернет-контенту під час вивчення іноземної мови / Англійська мова та література. К., 2011. №11. C. 8-13.

23 Pun M. Use of Multimedia Technology in English Language Teaching / Crossing the Border: International Journal of Interdisciplinary Studies. 2013. №1. C. 29-38.

24 Сысоев П. В., Евстигнеев М. Н. Современные учебные Интернет-ресурсы в обучении иностранному языку / Иностранные языки в школе. № 6. 2008. С. 2-9.

25 Титова С. В. Информационно-коммуникационные технологии в гуманитарном образовании: теория и практика. Пособие для студентов и аспирантов языковых факультетов университетов и вузов. М.: Издательский дом «КвинтоКонсалтинг», 2009. 240 c.

26 Чередніченко Г. А., Шапран Л. Ю., Куниця Л. І. Мультимедійні технології у процесі викладання дисципліни «Іноземна мова» у вищих технічних навчальних закладах / Наукові записки. Серія: Педагогіка. Тернопільський національний педагогічний університет ім. В. Гнатюка, 2011. № 4. С. 134-138.

27 Шилова С. А. Формирование гибких навыков средствами микрогрупповых форм работы при обучении иностранному языку в вузе / Известия Саратовского университета. Нов. сер. Сер. Акмеология образования. Психология развития, 2017. Т. 6, вып. 4 (24). С. 374-380.

\section{References}

1 Bykov, V. Yu. (2009). Pidvyshchennia znachushchosti informatsiino-komunikatsiinykh tekhnolohii v osviti. Pedagogy and psychology, 1, 28-33. [in Ukrainian]

2 Bykov, V. Yu., Kukharenko, V. M., Syrotenko, N. H., Rybalko, O. V., Bohachov, Yu. M. (2008). Tekhnolohiia stvorennia dystantsiinoho kursu. Kyiv, Millennium, 324 p. [in Ukrainian]

3 Bohdan, E. S. (2017). Razvitie u studentov inzhnernykh napravleniy soft skills kak vazhnyi faktor ikh konkurentosposobnosti. Actual problems of the humanities and natural sciences, 2-4, 17-20. [in Russian]

4 Bodnar, S. V. (2013). Vykorystannia Internet-tekhnolohii u systemi avtonomnoho vyvchennia profesiino-oriientovanoi inozemnoi movy studentamy nemovnykh spetsialnostei. Information technology and training tools, 2 (34), 75-81. [in Ukrainian]

5 Briggs, S. (2015). 30 Tips to Cultivate Soft Skills in Your Students, Open College.InformED. URL: https://www.opencolleges.edu.au/informed/features/30-ways-to-cultivate-soft-skills-in-your-students/ (accessed 02.01.2021).

6 Vasilieva, I. A. (2002). Psihologicheskie aspektyi primeneniya informatsionnyih tehnologiy. Issues of psychology, 3, 86. [in Russian]

7 Davydova, V. (2015). Slushat, govorit i dogovarivatsya: chto takoe soft skills i kak ih razvivat. URL: http:/l theoryandpractice.ru/posts/11719-soft-skills (accessed 02.01.2021). [in Russian]

8 Dluhunovych, N. A. (2014). Soft skills yak neobkhidna skladova pidhotovky IT-fakhivtsiv. Bulletin of Khmelnytsky National University, 6(219), 239-242. [in Ukrainian]

9 Koval, T. I. (2009). Pidhotovka vykladachiv vyshchoi shkoly: informatsiini tekhnolohii u pedahohichnii diialnosti. NLU publishing center, Kyiv, 380 p. [in Ukrainian]

10 Korniush, H. V. (2020). Formuvannia miakykh navychok u studentiv zakladiv vyshchoi osvity v konteksti navchannia inozemnykh mov. Teaching languages at higher education institions at the present stage. Cross-curricular relations, 36, 99-110. [in Ukrainian]

11 Kostenko, I. H. (2013). Vykorystannia Internet-resursiv na urokakh anhliiskoi movy. Tavriiskyi visnyk osvity, 1 (41), 170-176. [in Ukrainian]

12 Kostikova, I. I. (2006). Rol kompiuternykh tekhnolohii v navchanni studentiv. Novyi kolehium, 2 (33), 55-63. [in Ukrainian] 
13 Kukharenko, V. M. (2007). Dystantsiine navchannia. Entsyklopedychne vydannia. «Computer» Publishing center, Kyiv, 128 p. [in Ukrainian]

14 Lapinsky, V. (2011). Elektronni zasoby navchalnoho pryznachennia - svitovyi dosvid y ukrainska osvita. Higher education of Ukraine, 3, 487-495. [in Ukrainian]

15 Malinina, I. (2012). Blended Learning of English Language:Combining Online and Face-to-Face Teaching. Infonomic Society, London, 247-251.

16 Morska, L. I. (2008). Informatsiini tekhnolohii u navchanni inozemnykh mov. Ternopil, Aston, 256 p. [in Ukrainian]

17 Mosquera, I. (2018). Ideas to bring soft skills into the English classroom, British Council. Teaching English. URL: https://www.teachingenglish.org.uk/blogs/ingrid-mosquera-gende/ideas-bring-soft-skills-english-classroom (accessed 02.01.2021).

18 Nitchenko, H. M., Khovrych, M. O. (2015). Analiz vykorystannia informatsiino-komunikatsiinykh tekhnolohii u navchalnomu protsesi. Journal of Chernihiv national pedagogical university, 130, 169-172. [in Ukrainian]

19 Noskova, N.V., (2006), Informatyzatsiia systemy osvity ta problemy vprovadzhennia pedahohichnykh prohramnykh zasobiv u navchalnyi protses // Computer in school and family, Iss. 5, 7-11. [in Ukrainian]

20 Noskova, N. V. (2009). Problema motyvatsii pedahohiv do vykorystannia informatsiino-komunikatsiinykh tekhnolohii u navchalnomu protsesi. Computer in school and family, 1, 6-10. [in Ukrainian]

21 Palagutina, M. A. (2011). Innovatsionnyie tehnologii obucheniya inostrannyim yazyikam. Problems and prospects of the development of education: papers of international extramural scientific conference, Perm, Merkuriy, 156-159. [in Russian]

22 Pluhatarova, O. I. (2011). Vykorystannia internet-kontentu pid chas vyvchennia inozemnoi movy. English language and literature, 11. 8-13. [in Ukrainian]

23 Pun, M. (2013). Use of Multimedia Technology in English Language Teaching. Crossing the Border: International Journal of Interdisciplinary Studies, 1, 29-38.

24 Syisoev, P. V., Evstigneev, M. N. (2008). Sovremennyie uchebnyie Internet-resursyi v obuchenii inostrannomu yazyiku. Foreign languages at school, 6, 2-9. [in Russian]

25 Titova, S. V. (2009). Informatsionno-kommunikatsionnyie tehnologii v gumanitarnom obrazovanii: teoriya i praktika. Posobie dlya studentov $i$ aspirantov yazyikovyih fakultetov universitetov i vuzov. Kvinto-Consulting, Moscow, 240 p. [in Russian]

26 Cherednichenko, H. A., Shapran, L. Yu., Kunytsia, L. I. (2011). Multymediini tekhnolohii u protsesi vykladannia dystsypliny «Inozemna mova» u vyshchykh tekhnichnykh navchalnykh zakladakh. Scientific notes. Series: Pedagogy, Ternopil National Pedagogical University after V. Hnatyuk, 4, 134-138. [in Ukrainian]

27 Shilova, S. A. (2017). Formirovanie gibkih navyikov sredstvami mikrogruppovyih form rabotyi pri obuchenii inostrannomu yazyiku v vuze. Bulletin of Saratov University. New ed. Ed. Acmeology of education. Developmental psychology, 6 (24), 374380. [in Russian]



\author{
Щеглова Алла Олександрівна. \\ Старший викладач кафедри ділової іноземної мови та міжнародної комунікації, \\ Національний університет харчових технологій, \\ вул. Володимирська, 68, м. Київ, Україна, 01033. \\ Тел. +380972973579. E-mail: allegro89@bigmir.net
}

\title{
Shchehlova Alla Oleksandrivna.
}

Senior Teacher of Department of Business Foreign Language and International Communication, National university of food technologies,

Volodymyrska str, 68, Kyiv, Ukraine, 01033.

Tel. +38097 29735 79. E-mail: allegro89@bigmir.net

ORCID: https://orcid.org/0000-0002-6632-2753

Researcher ID: F-5469-2019

Citation (APA):

Shchehlova, A. (2021). Formation of HEls students' soft skills using distance learning platforms in foreign language teaching. Engineering and Educational Technologies, 9 (1), 28-39. doi: https://doi.org/10.30929/2307-9770.2021.09.01.03

\section{Цитування (ДСТУ 8302:2015):}

Щеглова А. О. Формування гнучких навичок у здобувачів вищої освіти при використанні платформ дистанційного навчання у викладанні іноземної мови / Інженерні та освітні технології. 2021. Т. 9. № 1. С. 28-39. doi: https://doi.org/10.30929/23079770.2021 .09 .01 .03

Обсяг статmі: $\quad$ сторінок - 12 ; умовних друк. аркушів - $1,738$. 